\title{
Multi-attribute compositional voting advice applications (MacVAAs) : a methodology for educating and assisting voters and eliciting their preferences
}

Citation for published version (APA):

Korthals, R. A., \& Levels, M. (2016). Multi-attribute compositional voting advice applications (MacVAAs) : a methodology for educating and assisting voters and eliciting their preferences. ROA. ROA Research Memoranda No. 004 https://doi.org/10.26481/umaror.2016004

Document status and date:

Published: 01/01/2016

DOI:

10.26481/umaror.2016004

Document Version:

Publisher's PDF, also known as Version of record

Please check the document version of this publication:

- A submitted manuscript is the version of the article upon submission and before peer-review. There can be important differences between the submitted version and the official published version of record.

People interested in the research are advised to contact the author for the final version of the publication, or visit the DOI to the publisher's website.

- The final author version and the galley proof are versions of the publication after peer review.

- The final published version features the final layout of the paper including the volume, issue and page numbers.

Link to publication

\footnotetext{
General rights rights.

- You may freely distribute the URL identifying the publication in the public portal. please follow below link for the End User Agreement:

www.umlib.nl/taverne-license

Take down policy

If you believe that this document breaches copyright please contact us at:

repository@maastrichtuniversity.nl

providing details and we will investigate your claim.
}

Copyright and moral rights for the publications made accessible in the public portal are retained by the authors and/or other copyright owners and it is a condition of accessing publications that users recognise and abide by the legal requirements associated with these

- Users may download and print one copy of any publication from the public portal for the purpose of private study or research.

- You may not further distribute the material or use it for any profit-making activity or commercial gain

If the publication is distributed under the terms of Article $25 \mathrm{fa}$ of the Dutch Copyright Act, indicated by the "Taverne" license above, 
Multi-attribute compositional voting advice applications (MacVAAs):

A methodology for educating and assisting voters and eliciting their preferences

Roxanne Korthals

Mark Levels

\section{ROA Research Memorandum}

ROA-RM-2016/4

Researchcentrum voor Onderwijs en Arbeidsmarkt | ROA Research Centre for Education and the Labour Market | ROA 


\title{
Multi-attribute compositional voting advice applications (MacVAAs): A methodology for educating and assisting voters and eliciting their preferences
}

\author{
Roxanne Korthals \\ Mark Levels \\ ROA-RM-2016/4 \\ February 2016
}

Research Centre for Education and the Labour Market

Maastricht University

P.O. Box 616, 6200 MD Maastricht, The Netherlands

$\mathrm{T}+31433883647 \mathrm{~F}+31433884914$

secretary-roa-sbe@maastrichtuniversity.nl

www.roa.nl

\footnotetext{
* The ROA Research Memorandum Series was created in order to make research results available for discussion, before those results are submitted for publication in journals.
} 


\section{Abstract \\ Multi-attribute composition voting advice applications (MacVAAs): A methodology for educating and assisting voters and eliciting their preferences**}

This paper introduces a technique to elicit voter preferences, by integrating multiattribute compositional analyses (Macs) with a voting advice application (VAA). The technique requires users to make trade-offs between different positions on a single issue, and between different issues. MacVAAs more closely resemble the electoral decision-making process in elections in which more than two parties participate than classic VAAs. MacVAA's also overcomes the assumption of issue orthogonality and assumption of rationality that classic VAA erroneously make. Results of a field application of the technique during the 2012 Dutch parliamentary elections in 2012 are presented. Advantages and disadvantages are discussed.

JEL classification: B40, D72

Keywords: voter assistance applications, elections, voters

Roxanne Korthals

Maastricht University

AE2

P.O. Box 616

6200 MD Maastricht

The Netherlands

r.korthals@maastrichtuniversity.nl
Mark Levels

Maastricht University

ROA

P.O. Box 616

6200 MD Maastricht

The Netherlands

m.levels@maastrichtuniversity.nl

** We would like to thank Zafer Büyükkececi and Merve Özer for useful comments that improved the paper. 


\section{Introduction}

In many European countries, voters increasingly use online Voting Advice Applications (Henceforth: VAAs) to help to decide how to vote during election time. The first VAA, using pen and paper, was launched in the Netherlands in 1989 (the Stemwijzer). VAAs are currently online during elections in many countries, e.g. Germany (Wahl-O-Mat), Belgium (Stemtest), Portugal (Bússola Eleitoral), Switserland (SmartVote), Ireland (Pick your party), Lithuania (Manobalsas). The objectives of these VAAs are twofold. First, they primarily aim to educate voters about the issues that are important during the coming election time, and about the position that political parties have about these issues (Cedroni and Garcia, 2010). Second, the VAAs are increasingly used for gathering data on voter opinions, which are then used for scientific studies (Mendez et al., 2014).

To educate voters and elicit their preferences, classic VAAs use variations on a common design (Cedroni and Garcia, 2010). They usually ask prospective voters for their opinion on a number of statements. From the answers the applications then provide a recommendation, either by reporting how well respondents' answers correspond with the positions of one or more parties on the presented items, or by presenting voters with their location on a multidimensional political plane. Data are stored and analyzed statistically. This method has some problems, which are widely discussed in literature. First, the provided advice is highly dependent on the choice of statements (Walgrave et al., 2009), which might be problematic as the range of statements does not necessarily cover the most important issues in the elections, the statements might not allow for enough discriminatory power between parties, political parties might have a large role in their positioning on the statements and the positioning of parties might not reflect the real position of the parties on the issues especially when political parties are allowed to fill in their own positions (Groot, 2003). Second, the advice is also sensitive to decision rules used to translate respondents' answers to 
recommendations (Kleinnijenhuis and Krouwel, 2008; Wagner and Ruusuvirta, 2012; Louwerse and Rosema, 2014). A third problem, most pressing when aiming to use VAAs for data gathering purposes, lies in the fact that VAA users usually are not representative for the population of countries' electorates (Wall et al., 2009).

The issues of sample representativeness and sensitivity to statement selection and calculation algorithms are widely acknowledged and well-studied. However, in light of recent findings from behavioral economics and experimental psychology, we argue that existing VAAs also suffer from more fundamental problems that are not yet sufficiently recognized. First, the assumption of issue orthogonality that underlies all existing VAAs is hardly realistic. That is, classic VAAs assume that voter and party positions on the various issues are independent of one another. However, deciding on a vote arguably involves more than having an opinions on a number of unrelated statements. When classic VAA's present solely independent statements on which the participants has to form an opinion, they falsely create the impression that voting does not actually require trade-offs. Second, VAA methodology strongly relies on the assumption of rationality. That is, the quality of recommendations strongly depends on the assumption that users' responses to items actually reflect the accurate outcome of a rational evaluation their preferences and interests (Downs, 1957As insights from psychology and behavioral economics show, decision-making is often distorted by various cognitive biases and misconceptions (Kahnemann and Tversky, 1979; Shafir and LeBoeuf, 2002). For example, voters might be aware a priori of their preference for a political party or position on the left-right spectrum and subconsciously answer the items in such a way that they end up with an advice for a party that they already had in mind. Classic VAA methodology can only deal with these issues in a limited way.

In this paper, we propose an innovative method for providing voter advice that does not require assumptions of issue orthogonality or rationality. This method exploits insights 
from multi-attribute compositional analysis (Mac, but also known as conjoint analysis, vignette studies, and stated preferences analyses) to elicit the political preference of voters. As such, the method requires that voters simultaneously take into account the positions of political parties on different issues. They have to weigh the position on one issue against a position on another issue. For example, using this method, voters cannot always choose to increase spending on health care and education without cutting on other posts or exceeding the budget. Our introduction of Mac in a VAA coincides with the recent call from Hainmueller et al. (2014) for the use of Mac in causal inference in survey experiment in the political field.

We argue that the multi-attribute compositional voter assistance application (or MacVAA) has three main improvements on existing VAAs. First, as it better mimics the actual decision-making process and reduces cognitive biases, it may be argued that MacVAA methodology provides a better advice on which party to vote for. Second, and related to the educational goal that VAAs have, MacVAAs not only educate people about important issues, but also educate them about the intrinsic complexity of electoral decision-making. The decision-making process mimics the reality political actors face when negotiating how to spend budgets and which laws to pass, and thus best reflects the reality of the political arena. The third advantage of the proposed method is that the obtained voter preferences can be used to make statements on the preferences of the public on the issues used in the application and also on the importance of the issues relative to each other. This information is not only relevant for public opinion researchers, but it could be also be vital information in countries that have a coalition system in which parties have to work together to form a government. To ensure the widest possible support for post-election negotiations, information on which positions and which issues are perceived to be most important by the electorate is an insightful tool. 
The paper is structured as follows. In the next section, we describe the theory and practise of VAA's and MacVAAs. In that section we provide the theoretical backgrounds and provide a general example of the MacVAA methodology. The third section describes how we field-tested a MacVAA during the Dutch 2012 Parliamentary elections and also describes results of this field-test. In the fourth and final section, we draw some conclusions.

\section{Theory and methodology}

There are many ways voters can arrive at a decision to vote for a particular party. One way in which voters decide on which party to vote for is by comparing their preferences on relevant issues with the stated positions of political parties on these issues (Franklin et al., 1992; Dalton, 1996). Cedroni and Garcia (2010) show that the theoretical model underlying issue preference voting is the so-called spatial model of rational decision-making (Downs, 1957). The spatial theory supposes that policies can be placed on a one-dimensional continuum. People decide who to vote for by comparing their own position on the continuum with the position taken by the various parties. To be able to do that, it is essential that (a) voters have a clear preference for certain policies, (b) parties have competing positions on these policies (Nie et al., 1979), and (c) voters are able to compare their own position on a certain policy to the position of the various parties (Butler and Stokes, 1969). To ensure that they are able to link their own preferences to those of parties, voters need information. However, information is costly to come by. To reduce the costs of information, VAAs are useful tools.

\subsection{Classic VAA's}

As said before, VAAs have two goals: The first is to help voters in their choice for which party to vote for and to learn something about political choices in the process. The second is to be able to elicit voter preferences. Most VAAs achieve these goals by presenting users with 
a sequence of consecutive propositions, about which both users and parties are assumed to have an opinion. To use an example from the 2012 Dutch Stemwijzer, the set of items that users were presented with included the following items (translated verbatim) ${ }^{1}$ :

[1] The deficit on the government budget should not exceed 3\% in 2013.

[12] Government should stop providing students with subsidies. From now on, students should loan money for their studies.

[19] The tax deductibility of mortgage interests should not be limited any further.

In response to these and other propositions, VAA users have to state their preference, most often on a Likert scale. In case of the Stemwijzer, a three point Likert scale is used, so users have to state whether they "Agree", "Disagree" or have "No opinion". This exercise is repeated for a set number of issues. An algorithm is then used to determine the congruence between the users' stated preferences on the various issues and the various parties' positions on the issues.

\subsection{Limitations to classic VAA's}

Classis VAA's have multiple well known limitations (sample representativeness, sensitivity to issue selection, and sensitivity to the calculation algorithms), but two more fundamental limitations exist. First, the subsequent nature of item presentation by definition assumes that voters' and party preferences on the items are orthogonal. This assumption of orthogonality is demonstrably unrealistic. Parties base their campaign programs on a more or less logically consistent and coherent set of ideological base principles. As a consequence, positions taken by political parties are seldom uncorrelated, even in highly fractionalized multi-party systems. For example, parties that favor strong welfare states are also more likely to oppose labor

1. http://www.stemwijzer.nl/TK2012/index.html, last accessed on July 30, 2015. 
market flexibilisation, and parties that oppose tax increases usually also argue for strong national defenses (Janssen, 2010).

The assumption of orthogonality is also violated due to voter preferences. Hardly anybody fully agrees with all the positions of a political party, so the decision which party to vote for requires balancing the positions of different parties. Ideally, voters have to weigh the positions on different issues for each party and decide how to vote based on all the positions of all the issues by all the parties simultaneously. Moreover, voters might also assign different levels of importance to the various issues, to the extent to which they might choose one party over another solely because they agree with that party on a particular issue that is crucial to them, or they refuse to vote for one party because they disagree on one specific issue. Voters might be consciously aware of their own opinions on most issues, but they might not know their preferred rank-order of the various issues until they are forced to consciously evaluate the relative importance of the various issues that are politicized during election campaigns. Classic VAAs evade this important and educating part of the decision-making process. This is misleading, and may raise in voters unrealistic and false expectations of election outcomes. In our proposed MacVAA voters have to base their choice on all the positions of all the issues simultaneously.

Second, classic VAAs assume that voters do have conscious prior preferences about which party to vote for in any given election, the assumption of rationality. Preferences may be fully rational in the sense that they reflect their best interests in this particular election, but that does not necessarily have to be the case. For example, voter preferences may be subject to bandwagon effects, where voters unwittingly adjust their preferences for political parties to align with perceived majority preferences (e.g. Nadeau, Cloutier and Guay, 1993; Mehrabian, 1998; McAllister and Studlar, 1991; Goidel and Shields, 1994; Morwitz and Pluzinski, 1996). Relatedly, it is long recognized that people base their party preferences on the preferences of 
significant others (see for example: Campbell et al., 1960; Butler and Stokes, 1969; Sears, 1975; Rose and McAllister, 1986), which may subject voting behavior to social desirability bias. Third, party preferences may be subject to cognitive inertia, in the sense that voter preferences may reflect their actual voting behavior in previous elections, while their beliefs about which party program best reflects their current interests may be outdated as in the meantime party programs may have changed. When presented with a thesis in a VAA, users may be guided by assumptions about the position on this issue that is held the party of their preferences. Confirmation bias will ensure that statements associated with preferred parties will be judged more favorably, and reactive devaluation (Lee and Constance, 1991) will ensure that the opposite happens to statements associated with parties one disagrees with. As a result, the outcome of the recommendation of VAAs may very well be a self-fulfilling prophecy. Note that this distortion is more severe if users are more well-informed. If this is the case, then the extent to which any recommendation algorithm is capable of producing a valid voting advice based on revealed preferences is limited. These issues caused by cognitive biases can be overcome by presenting the information in a way that does not assume orthogonality of issues or rationality of users, and as such, are a more realistic representation of the decision-making process. Our proposed MacVAA does exactly that. Hainmueller et al. (2014) also recognize that Mac's does not require the assumption of rationality since Mac's can estimate voter preferences "irrespective of the underlying behavioral model" (p.3).

\subsection{MacVAA}

We introduce a new technique to elicit voter preferences which integrates multi-attribute compositional analyses (Green, 1974; Louviere 1988; Gustavson et al., 2003) with a VAA and elevates the above described biases. Multi-attribute compositional analysis is used frequently in marketing and related fields to elicit prospective decision-makers' stated 
preferences about items that have multiple interdependent attributes. In a multi-attribute compositional analysis participants are presented with a sequence of decisions between a number of items that have a multiple characteristics that are relevant for the purchasing decision. Because of the multi-attribute nature of the items, prospective decision-makers have to make trade-offs between different varying characteristics of the item. The classic example is the decision to buy a car. Cars can be cheap or expensive, red or blue, have a maximum speed of 85 or 120 miles per hour, have a low mileage or a high one, etcetera. When asked, rationally calculating respondents should prefer a cheap car, with a low mileage, but a maximum speed of 120 miles per hour. However, such a car is unrealistic. In practice, attributes of cars are not orthogonal. As price and performance of cars covary, it would be more realistic to choose between a car that has a low mileage, is cheap and has a maximum speed of 85 miles per hour and a car that is expensive and can reach 120 miles per hour. Or perhaps respondents would be willing to compromise on the mileage to get the color they want.

The choice voters have to make during elections is essentially very similar to the choice faced by a person who wants to buy a car. Voters have to choose between two or more parties. Parties take positions on various issues that may be important to voters to a varying degree. These positions can be seen as observable values of the parties. Hardly any voter will agree with all the positions of a single party. Rather, voters may choose for the party with which they agree the most or with which they agree on the most crucial issues. Voters will then make a trade-off between the positions on different issues from a single party, and between the different positions on a single issue of multiple parties. Voters have to weigh how important the respective issues are to them, and then decide on which party they like best.

To exemplify how MacVAAs model these complex choice processes, figure 1 presents an example of a VAA using fictional political parties' election programs. It depicts three 
fictive political parties and their positions on five issues. The three political parties are referred to as three vignettes, while the different issues are called attributes and the positions are values of the attributes. This example simplifies the choice of which political party to vote for to a trade-off between different issues and different positions on those issues. MacVAA methodology does exactly that: it presents participants with a trade-off between three fictive party programs and it does so a fixed number of times. Each time the values to the attributes are allocated at random among the fictive parties and each time the participant is required to choose one party program over the other two. At the end of the application, participants have thus been repeatedly presented with a fixed number of choices, each between three fictive party programs. Some of these might have reflected the positions of existing parties, but due to the random nature of the way attributes are assigned to vignettes, most will not represent existing parties, and might not even be realistic.

Figure 1. Fictional example of one choice set (containing three vignettes)

\begin{tabular}{llll}
\hline & Party 1 & Party 2 & Party 3 \\
\hline Education spending & Increase it & Lower it & Increase it \\
Social security & Make it more generous & Keep it like it is & Lower access \\
Renewable energy & Eliminate subsidies & Subsidize & Subsidize \\
Health care costs & Lower them & Increase them & Make them income dependent \\
Government budget deficit & $>3 \%$ is allowed & Keep it $<=3 \%$ & $>3 \%$ is allowed \\
\hline
\end{tabular}

The choice of program within each choice set reveals part of participants' preferences. Taking the decisions participants made in all the different choice sets allows for eliciting their overall preferences. At the end of the application, participants can then be presented with an overview of the similarity between their positions on the issues covered and the positions of the available parties. 
Note that the attributes must correspond to issues that may be electorally important, and that the values of the attributes come from the positions that various parties take on these issues. Also note that where classic VAA designs assume that these issues are orthogonal, the multi-attribute design does not require this. MacVAAs by design reduce the effects of confirmation bias in two ways. First, issues are not phrased as theses, but as attributes of party programs. These programs do not necessarily correspond with actual party programs, which make linking programs to previously held preferences for political parties very cognitively demanding. Second, decision-making is less distorted by confirmation bias since the choice options are presented simultaneously, rather than sequentially (Jona et al., 2001).

\section{MacVAA in practice: De Politieke Weegschaal}

In this section, we describe how we field-tested a MacVAA in the 2012 Dutch Parliamentary Elections under the name Politieke Weegschaal (Political Scale, henceforth: PW). We describe the context, and provide concrete descriptions of our mode of operations and the decisions we made.

\subsection{Context}

On the $23^{\text {rd }}$ of April in 2012 the Dutch government stepped down and new elections were announced. During this election 21 political parties were on the ballot and voters had to choose one person from one party. From the results of this election two parties together formed a majority in parliament. A few weeks after the Dutch government stepped down all 21 political parties had presented preliminary programs for the upcoming years. In June most parties had a final version of their programs. Because the summer period was in between the fall of the government and the new elections, the campaign was short but intense with a 
number of final debates at the beginning of September. The elections were held the $12^{\text {th }}$ of September 2012.

\subsection{Issue selection}

One of the main decisions that VAA developers have to make is which issues to adopt in the instrument. This is crucial to the outcome. For instance, Groot (2003) criticizes the StemWijzer and the specific statements and the party positioning it used in the 2002 national elections. Groot (2003) argues that the range of statements did not cover the most important issues in the elections, the statements did not allow for enough discriminatory power between parties, political parties had a too large role in their positioning on the statements and that in other instances the positioning of parties did not seem to reflect the real position of the parties on the issues. Walgrave et al. (2009) argue that the choice of statements in a VAA has a large impact on the resulting recommendations. They arrive at different recommendations for the same people if they use varying sets of 36 statements from a sample of 50 statements.

In the field test, we, first, searched the actual party programs for matching issues and then categorized party positions on these issues. We limited ourselves to the 10 political parties that already had seats in parliament. In order to be adopted in the VAA, issues had to be important during elections, but practical limitations also existed, as not all parties expressed positions on all relevant issues. To identify issues important for voters, we used a clear decision-rule. Issues were eligible for adoption in our MacVAA if and only if they satisfied two conditions: 1) they had to be among the largest posts on the annual government budget, and 2) all parties had an expressed position on them in their election program.

Multi-attribute compositional tests are highly cognitively demanding (RamirezHuartardez, 2009). To prevent users from dropping out, we limited the number of issues (the attributes) to 7 and the maximum number of positions on these issues (the values) to 4 . The 
seven issues (attributes) we used are the study subsidy of bachelor students, the duration and amount of unemployment benefits, the policy to tax car use by the kilometer, renewable energy, the tax deductibility of mortgage costs, health care deductibles and the government finances. The first six were major items on the budget, either in the sense of revenues or of costs, the last one is an attribute regarding the budget itself. In almost all instances did political parties mention their position on the issue in their program. The parties were either in favor, against it or preferred the status quo and we categorized them accordingly. Figure 2 presents all attributes and values we used in the field test.

Figure 2. Attributes and values of the PW

\begin{tabular}{|c|c|c|c|c|}
\hline Attributes/Political issues & Values/Politic & I positions & & \\
\hline Education: study subsidy bachelor & $\begin{array}{c}\text { Change into a } \\
\text { social loan } \\
\text { system }\end{array}$ & Maintain it & & \\
\hline $\begin{array}{l}\text { Social security: Unemployment } \\
\text { benefits: duration and amount }\end{array}$ & Shorten it & $\begin{array}{l}\text { Shorten it but } \\
\text { higher amount }\end{array}$ & Maintain it & \\
\hline $\begin{array}{l}\text { Transportation: car use taxed by } \\
\text { the kilometer }\end{array}$ & $\begin{array}{l}\text { (Gradually) } \\
\text { implement it }\end{array}$ & Neutral & $\begin{array}{l}\text { Do not } \\
\text { implement it }\end{array}$ & \\
\hline Renewable energy & $\begin{array}{l}\text { Eliminate } \\
\text { subsidies }\end{array}$ & $\begin{array}{c}\text { Subsidize } \\
\text { and/or make it } \\
\text { mandatory }\end{array}$ & & \\
\hline $\begin{array}{l}\text { Housing: tax deductibility of } \\
\text { mortgage costs }\end{array}$ & $\begin{array}{l}\text { (Gradually) } \\
\text { abolish it }\end{array}$ & Limit it & Maintain it & \\
\hline Health care: deductibles & Increase them & $\begin{array}{l}\text { Make them } \\
\text { income } \\
\text { dependent }\end{array}$ & Neutral & Lower them \\
\hline $\begin{array}{l}\text { Finances: government budget } \\
\text { deficit }\end{array}$ & Keep it $<=3 \%$ & $\begin{array}{l}>3 \% \text { is } \\
\text { allowed }\end{array}$ & & \\
\hline
\end{tabular}

Krouwel et al. (2014) argue that the party positions on the statements used in the VAAs should best be based upon expert opinions combined with information from the party programs. We consulted with the political parties whether they agreed with our categorization. We did however not change a party position in the field test without a valid 
reasoning from the party representative, which was based on explicit quotations from election programs that proved our categorization wrong.

\subsection{Recommendation}

From users' answers, we derived a recommendation. Literature shows that the algorithm with which recommendations are computed is crucial. For example, Kleinnijenhuis and Krouwel (2008) argue that VAAs work best when the recommendations are based upon a multidimensional scale. The authors compare three VAAs (StemWijzer, Stemtest, and the second largest Dutch VAA Kieskompas) which all use different decision rules for the recommendation. The StemWijzer solely counts the number of statements the participants agrees with each party, the Stemtest weights these answers using the relative dominance of the issues in each party's program and the Kieskompas adds another feature, namely that both the parties and the participants are positioned on a two dimensional plane. Wagner and Ruusuvirta (2012) compare thirteen VAAs in seven European countries to elicit the model on which the recommendations are based. Most VAAs are able to match voters to parties relatively well using "issue based proximity models", but do less well on smaller issues which are prominent in fewer statements. Also Louwerse and Rosema (2014) are concerned with the calculation of the recommendation as they find that participants of the StemWijzer would have received different recommendations if different calculation methods were used.

In accordance with this literature, we decided to use a simple and straightforward algorithm for computing a voting recommendation. For each fictive party program we calculated the percentage which the program had in common with the program of each actual political party. Using these percentages, we calculated the average percentage of agreement between the chosen fictive parties by the applicants for each party. The applicant was then presented with a list of percentages, one percenatge for each actual political party, which 
indicated for each party how much the choices of the applicant were in common with the party program of that party.

\subsection{Marketing}

We were able to obtain some (local) publicity but the PW was mostly reached through social media and personal contacts. There was some local news coverage for the PW in the province of our university (Radio station L1, university magazine De Observant), the PW was included in a number of lists of different VAAs available to voters (e.g. the website of the national magazine Elsevier) and on some blogs (e.g. Maastricht Aktueel). However, the primary news source through which our users found out about the PW was social media. We had set up a twitter and Facebook account and ask all our friends to spread the word.

\subsection{Field-test}

On August 18, we launched the PW. The MacVAA was online until one day after the elections, e.g. September 12, 2012. In the four weeks leading up to the Dutch national elections in 2012 the PW was consulted 4954 times and participants together saw 173,391 choices. In theory every participant viewed 15 choice sets of 3 options, thus leading to 45 observations per participant. However, 1435 participants did not finish the application and thus did not view all 15 choice sets. ${ }^{2}$ We logged the choices made by all respondents, as well as their stated answers on some background characteristics.

2. For some time we had server problems which prevented participants from finishing the application. However, follow up interviews revealed that the application was considered too time consuming by some, and that some participants stopped using the application prematurely. 


\subsection{Analyses}

Data from MacVAAs can be used to elicit information about voter preferences. ${ }^{3}$ Three types of information can be derived: 1) information about the extent to which attributes increase the probability that a party program is chosen over others, 2) information of the relative importance of issues for party choice, and 3) information about the popularity of actual party programs. To exemplify the potential applicability of MacVAAs for voter opinion research, we perform three such analyses using actual data we obtained from the field test.

First, MacVAA data can be used to elicit the relevance the various attributes have for the decision between party programs. To this end, we analyzed the data from the field tested multi-attribute compositional VAA with a conditional fixed effect logistic regression, to take into account the dependency between the three options in each choice set, and we cluster on individuals. The results in Table 1 show that a party program ("vignette") is more likely to be chosen if it states that the study subsidy and the unemployment benefits are maintained, car use will not be taxed by the $\mathrm{km}$, renewable energy stimulation is intensified, the tax deductibility of mortgage costs is limited, health care deductibles are either made income dependent or are lowered and the government budget in 2012 will be below three per cent (as required by the European Union).

Table 1. The impact of positions on political issues on the probability that the party program is chosen (odds ratios)

\begin{tabular}{lc}
\hline Attribute & $\begin{array}{c}\text { Contribution of attribute to the } \\
\text { probability that a party program } \\
\text { is chosen }\end{array}$ \\
\hline $\begin{array}{l}\text { Education: study subsidy bachelor } \\
\text { maintain it } \\
\text { change into a social loan system }\end{array}$ & ref \\
& $0.73^{* * *}$ \\
& $(0.023)$
\end{tabular}

3. Data are for the most part subject to the same limitations that data from other VAAs are subject to. More information about data is presented in the Data Appendix. 
Social security: Unemployment benefits: duration and amount maintain it

shorten it

shorten it but higher amount

Transportation: car use taxed by the kilometer

Neutral

ref

(Gradually) implement it

Do not implement it

Renewable energy

Subsidize and/or make it mandatory

Eliminate subsidies

Housing: tax deductibility of mortgage costs

Maintain it

ref

(Gradually) abolish it

$0.88 * * *$

Limit it

Health care: deductibles

Neutral

ref

Increase them

$0.489 * * *$

Make them income dependent

Lower them

Finances: government budget deficit

$>3 \%$ is allowed

ref

Keep it $<=3 \%$

Observations

Clusters

Pseudo $\mathrm{R}^{2}$ 0.0858

Notes: Standard errros in parentheses. The superscripts $*, * *$, and $* * *$ indicate significance at the $10 \%, 5 \%$, and $1 \%$ levels, respectively. Table shows estimates which are weighted, grouped at id and choice set, and clustered at the individual level.

The results indicate that voters in the 2012 Netherlands' election would like to increase their own benefits without exceeding the government budget. ${ }^{4}$ However, participants appear to be

4. The results should of course not be generalized to the entire population given the limitations of the sample, as also discussed in the data appendix. 
willing to limit the tax deductibility of mortgage costs, a policy that would be negative for all home owners.

In addition to the identification of positions, it is possible from the above presented results to obtain an importance ranking of issues by users, using the following equation:

$$
\text { importance }_{i}=\frac{\left|\bar{x}_{i}\right|-\left|\underline{x}_{i}\right|}{\sum_{i=1}^{I}\left|\bar{x}_{i}\right|-\left|\underline{x}_{i}\right|}
$$

where the relative importance of attribute $i$ is dependent on the absolute difference between the highest and lowest coefficient of the values of a single attribute over the sum of absolutes differences of all the attributes. This measure of relative importance is very similar to the average marginal component effect of Hainmueller et al. (2014).

Table 2 states that health care and the government finances were the most important aspects of party programs, as we elicit from the choice of participants. Thus although maintaining or only limiting the tax deductibility of mortgage costs is preferred by the participants, they would rather keep the budget deficit below 3 per cent.

Table 2. Importance of the different issues for voter preferences

\begin{tabular}{lc}
\hline Issues & Importance \\
\hline Health care: deductibles & 0.21 \\
Finances: government budget deficit 2013 & 0.21 \\
Renewable energy & 0.19 \\
Education: study subsidy bachelor & 0.16 \\
Social security: Unemployment benefits: duration and amount & 0.10 \\
Transportation: car use taxed by the kilometer & 0.07 \\
Housing: tax deductibility of mortgage costs & 0.06 \\
\hline
\end{tabular}

Notes: Results based on equation (1) and the results in Table 1.

All age and gender groups care most about health care: either increasing deductibles or making them income dependent. The least important issue for older people (45 and up) and men is the tax deductibility of mortgage costs. While women and people under 45 care least about the policy to tax car use by the kilometer. People below 45 rank the importance of the 
study subsidy for bachelor students as third important, and people under 25 rank it as second most important issue. ${ }^{5}$

A third type of information that can be obtained from multi-attribute compositional surveys regard the popularity of real choice options, which can be seen as a combination of the first two analyses. These analyses provide information interesting for political parties when new party programs have to be written. The vignettes most often and least often chosen in our field test are depicted in Figure 3. The most often chosen vignette was chosen 70 per cent of the time it was shown, the vignette least chosen was only chosen in 4 per cent of cases. The information distilled from Figure 3 is very similar to that seen in Table 1 and 2.

\section{Figure 3. Most and least often chosen vignettes.}

\begin{tabular}{ll}
\hline Chosen most often & Chosen least often \\
\hline Education: study subsidy bachelor: & Education: study subsidy bachelor: \\
maintain it & change into a loan system \\
Transportation: car use taxed by the kilometer: & Transportation: car use taxed by the kilometer: \\
neutral & neutral \\
Social security: Unemployment benefits: & Social security: Unemployment benefits: \\
duration and amount: maintain it & duration and amount: shorten it \\
Renewable energy: & Renewable energy: \\
Subsidize and/or make it mandatory & Eliminate subsidies \\
Housing: tax deductibility of mortgage costs: & Housing: tax deductibility of mortgage costs: \\
Limit it & Maintain it \\
Health care: deductibles: & Health care: deductibles: \\
Make them income dependent & Increase them \\
Finances: government budget deficit: & Finances: government budget deficit: \\
Keep it <=3\% & $>3 \%$ is allowed \\
\hline
\end{tabular}

\section{Conclusion and discussion}

VAAs are increasingly important instruments that voters can use to determine their vote during elections. Empirical studies show that VAAs do affect voter behavior. Walgrave et al. (2006) find effects on final voter decisions of the use of a VAA in the Belgium elections in

5. Results available on request. 
2004. Similar evidence exists for voters in Switzerland (Fivaz et al., 2010). Wall et al. (2014) show that in the Netherlands especially voters who had preferences for multiple parties before consulting the VAA were more likely to follow the recommendation by the VAA. Ruusuvirta and Rosema (2009) find similar results and also find a small effect of VAAs on voter turnout.

The quality of VAAs thus is an academic discussion with direct real-life implications. Although there are VAAs in a number of countries and there is made some headway in improving the existing VAAs, as far as we know, all VAAs share a design that relies on the subsequent presentation of statements. In this contribution, we identified two unrealistic assumptions that underlie this design, i.e. the issues of issue orthogonality and the issue of rational decision-makers. We show that these two assumptions increase the probability that decision-making using classic VAAs is distorted and that classic VAAs unjustly present electoral decision-making as a decision without tradeoffs. To counter this, we presented the methodology of an innovative integration of multi-attribute compositional research designs and voting advice applications (MacVAAs). We also presented results from a field experiment done with a MacVAA.

It is important to note that the MacVAA model suffers from many of the limitations of classical VAAs. For instance, as is the case with classic VAAs, the outcome is highly dependent on the selection of issues that are adopted in the instrument (Groot, 2003; Walgrave et al., 2009; Krouwel et al., 2014). It could be argued that this problem is even more pressing for MacVAAs, since the relatively high cognitive demand the multi-attribute design places on users, naturally limits the number of issues that can be addressed.

Nonetheless, MacVAA methodology arguably improves on classic VAAs in three main ways. First, we argued that the multi-attribute design provides a better way to educate voters on the political process in which trade-offs are often present. Second, MacVAAs provide voters with a voting advice that is less distorted by cognitive biases. Third, they 
potentially provide researchers with a more reliable way to elicit voter preferences, to be used either for academic interest or for politicians to understand election results. In that sense, we argue that multi-attribute compositional voting advice applications fulfill the key functions of VAAs better than the classic design does. 


\section{References}

Butler, D. and D. Stokes. 1969. Political change in Brittain: Forces Shaping Electoral Choice. New York: St. Martin's.

CBS Statistics Netherlands. 2012. Beroepsbevolking; behaalde onderwijs naar herkomst geslacht en leeftijd. Obtained from www.cbs.nl 10-10-2012.

Campbell, A., P. Converse, W. Miller, and D. Stokes. 1960. The American Voter. Chicago: University of Chicago Press.

Costa Lobo, M., M. Vink and M. Lisi. 2010. Mapping the Political Landscape: A Vote Advice Application in Portugal (October 20, 2010). In L. Cedroni and D. Garzia (eds) Voting Advice Applications in Europe: The State of The Art: 139-166. Napoli: Scriptaweb.

Dalton, R. 1996a. Political Cleavages, Issues, and Electoral Change. In L. LeDuc, R. Niemi and P. Norris (eds.) Comparing Democracies. Elections and Voting in Global Perspective: 319-342. London: Sage Publications.

Downs, A. (1957). An Economic Theory of Democracy. New York: Harper.

Fivaz, J., J.Pianzola, and A. Ladner. 2010. More than toys: a first assessment of voting advice applications' impact on the electoral decision of voters Challenges to Democracy in the 21st Century. National Centre of Competence in Research Working Paper Serie: Working Paper no. 48.

Franklin, M., T. Mackie and H. Valen. 1992. Electoral change. Responses to evolving social and attitudinal structures in Western societies. Cambridge: Cambridge University Press.

Goidel, R., K. Shields and G. Todd. 1994. The Vanishing Marginals, the Bandwagon, and the Mass Media. The Journal of Politics 56: 802-810. 
Green, P. 1974. On the Desing of Choice Experiments Involving Multifactor Alternatives, Journal of Consumer Research 1: 61-68.

Groot, L. 2003. Criteria to Evaluate Voting Indicators and a Recipe for a New One. SISWO: 2003

Gustafsson, A.; Herrman, A. and Huber, F. (2003). Conjoint Measurement. Methods and Applications. Springer-Verlag, Berlin.

Hainmueller, J., D. Hopkins, and T. Yamamoto. 2014. Causal Inference in Conjoint Analysis: Understanding Multidimensional Choices via Stated Preference Experiments. Political Analysis 22 (1): 1-30

Kahneman, D and A. Tversky. 1979. Prospect Theory: An Analysis of Decision under Risk. Econometrica 47(2): 263

Kahneman, D. and S. Frederick. 2002. Representativeness Revisited: Attribute Substitution in Intuitive Judgment. In T. Gilovich, D. Griffin, and D. Kahneman (eds). Heuristics and Biases: The Psychology of Intuitive Judgment: 49-81. Cambridge: Cambridge University Press.

Kleinnijenhuis, J., and A. Krouwel. 2008. Simulation of decision rules for party advice websites. In: F. Welsch, J. Carrasquero, A. Oropeza, and C. Chen (eds.) Proceedings of the 2nd International Multi-Conferenceon Society, Cybernetics and Informatics: 138-145. IIIS, Orlando.

Krouwel, A. and A. van Elfrinkhof. 2014. Combining strengths of methods of party positioning to counter their weaknesses: the development of a new methodology to calibrate parties on issues and ideological dimensions. Quality \& Quantity 48(3): 1455-1472.

Louviere, J. 1988. Analyzing Decision Making. Metric Conjoint Analysis, Newbury Park, Sage Publications Inc. 
Louwerse, T. and M. Rosema. 2014. The design effects of voting advice applications: Comparing methods of calculating matches. Acta Politica 49: 286-312.

McAllister, I., and D. Studlar. 1991. Bandwagon, Underdog, or Projection? Opinion Polls and Electoral Choice in Britain, 1979-1987. The Journal of Politics 53: 720-740

Mendez, F., K. Gemenis and C. Djouvas. 2014. Methodological Challenges in the Analysis of Voting Advice Application Generated Data. In: 9th International Workshop on Semantic and Social Media Adaptation and Personalization (SMAP), Corfu, 6-7 November 2014: $142-148$.

Mehrabian, A. 1998. Effects of Poll Reports on Voter Preferences. Journal of Applied Social Psychology 28 (23): 2119-2130

Morwitz, V. and C. Pluzinski. 1996. Do Polls Reflect Opinions or Do Opinions Reflect Polls? Journal of Consumer Research 23 (1): 53-65.

Nadeau, R., E. Cloutier and J. Guay. 1993. New Evidence About the Existence of a Bandwagon Effect in the Opinion Formation Process. International Political Science Review 14 (2): 203-213

Nie, N., S. Verba, and J. Petrocik, 1979. The Changing American Voter. Cambridge: Harvard University Press.

Ramirez-Huartardez, J. 2009. Measuring: from Conjoint Analysis to Integrated Conjoint Experiments. Journal of Quantitative Methods for Economics and Business Administration 9: 28-43

Ross, L. and C. Stillinger 1991. Barriers to conflict resolution. Negotiation Journal 8: 389404.

Ruusuvirta, O. and M. Rosema. 2009. Do online vote selectors influence electoral participation and the direction of the vote? Paper presented at the European 
consortium for Political Research (ECPR) General Conference, Potsdam, Germany, 10-12 September 2009.

Sears, D. 1975. Political Socialization. In F.I. Greenstein \& N.W. Polsky (eds.) Handbook of Political Science Volume 2 Micropolitical theory: 93-153. Reading (MA): AddisonWesley

Shafir, E. and R. LeBoeuf. 2002. Rationality. Annual Review of Psychology 53 (1): 491-517

Wagner, M. and O. Ruusuvirta. 2012. Matching Voters to Parties: Voting Advice Applications and Models of Party Choice. Acta Politica 47: 400-422.

Walgrave, S., M. Nuytemans and K. Pepermans. 2009. Voting Aid Applications and the Effect of Statement Selection, West European Politics 32(6): 1161-1180.

Walgrave, S., P. Van Aelst and M. Nuytemans. 2006. 'Do the vote test'. Electoral effects of a vote advice application at the 2004 Belgian elections. Paper prepared for delivery at ECPR joint workshop sessions, April 2006, Nicosia, Cyprus.

Wall, M., M.L. Sudulich, R. Costello and E. Leon. 2009. Picking your party online - An investigation of Ireland's first online voting advice application. Information Polity 14: 203-218.

Wall, M., A. Krouwel and T. Vitiello. 2014. Do voters follow the recommendations of voter advice application websites? A study of the effects of kieskompas. nl on its users' vote choices in the 2010 Dutch legislative elections. Party Politics 20(3): 416-428. 


\section{DATA APPENDIX}

Data obtained through MacVAAs can be used for public opinion research. In this paper, we aimed to provide examples of the types of information that can be elicited using MacVAAs. It should be noted that many of the caveats that apply to classic VAAs also apply to MacVAAs. For example, since most of our users learned about the PW from social media, we did not obtain a representative sample of the Dutch population. Wall et al. (2009) look at the elections in Ireland in 2007 and find that the users of VAA were not a representative sample of the Irish population and that people inclined to vote for two of the main parties in Ireland were not identified as such.

Data elicited with a MacVAA suffer from the same problem in which the sample is not representative for the population. In our sample, higher educated and men are overrepresented. Table 1 compares our sample to the Dutch population. To be able to make statements on the voter preferences of the Dutch population, in our analyses we weight our observations to the population distribution. With this in mind we delete all users for which we do not have the age, gender or the educational level and those above the age of 74 since for people of 75 and above CBS Statistics Netherlands does not provide information. This leaves us with a total of 147,513 observations, coming from 2998 participants who completed the application and 1186 participants who did not finish.

Another common issue we cannot address is that some people might have consulted our application multiple times. Especially participants who did not finish the application in their first try might have tried again at a later moment. These participants will be in our database twice since we cannot identify them. In the following analyses, we delete all users under the age of 18 since they were not eligible to vote. We further delete those for which the education level could not have been obtained with certain ages. 
Table A1. Population and sample distribution

\begin{tabular}{|c|c|c|c|c|c|c|c|c|c|c|}
\hline Gender: & Men & & & & & Wome & & & & \\
\hline Educational & Prim. & Pre-voc. & Voc. \& & Tert. & Total & Prim. & Pre-voc. & Voc. \& & Tert. & Total \\
\hline level: & edu. & sec. edu. & gen. & edu. & & edu. & sec. edu. & gen. sec. & edu. & \\
\hline & & & sec.edu. & & & & & edu. & & \\
\hline & & & & Dutch & spulatio & & & & & \\
\hline $15<$ age $<25$ & 0.007 & 0.036 & 0.044 & 0.003 & 0.090 & 0.005 & 0.033 & 0.044 & 0.006 & 0.088 \\
\hline $25>$ age $<=35$ & 0.003 & 0.011 & 0.046 & 0.019 & 0.078 & 0.002 & 0.008 & 0.042 & 0.023 & 0.076 \\
\hline $35>$ age $<=45$ & 0.004 & 0.014 & 0.052 & 0.022 & 0.091 & 0.003 & 0.014 & 0.056 & 0.021 & 0.094 \\
\hline $45>$ age $<=55$ & 0.005 & 0.017 & 0.053 & 0.021 & 0.096 & 0.006 & 0.020 & 0.057 & 0.017 & 0.100 \\
\hline $55>$ age $<=65$ & 0.006 & 0.014 & 0.043 & 0.018 & 0.081 & 0.009 & 0.025 & 0.037 & 0.012 & 0.082 \\
\hline age $>65$ & 0.007 & 0.013 & 0.033 & 0.010 & 0.063 & 0.010 & 0.021 & 0.024 & 0.005 & 0.060 \\
\hline Total & 0.031 & 0.106 & 0.269 & 0.093 & 0.499 & 0.035 & 0.121 & 0.260 & 0.084 & 0.501 \\
\hline & & & & Our & ample & & & & & \\
\hline $15<$ age $<25$ & 0.003 & 0.004 & 0.048 & 0.040 & 0.095 & 0.002 & 0.004 & 0.033 & 0.040 & 0.078 \\
\hline $25>$ age $<=35$ & 0.000 & 0.004 & 0.038 & 0.150 & 0.192 & 0.000 & 0.001 & 0.019 & 0.090 & 0.110 \\
\hline $35>$ age $<=45$ & 0.000 & 0.004 & 0.034 & 0.092 & 0.130 & 0.000 & 0.002 & 0.023 & 0.054 & 0.080 \\
\hline $45>$ age $<=55$ & 0.000 & 0.006 & 0.028 & 0.064 & 0.098 & 0.000 & 0.003 & 0.024 & 0.040 & 0.068 \\
\hline $55>$ age $<=65$ & 0.000 & 0.006 & 0.022 & 0.044 & 0.073 & 0.000 & 0.004 & 0.010 & 0.029 & 0.044 \\
\hline age $>65$ & 0.000 & 0.001 & 0.005 & 0.014 & 0.021 & 0.000 & 0.001 & 0.004 & 0.005 & 0.010 \\
\hline Total & 0.004 & 0.026 & 0.176 & 0.404 & 0.610 & 0.002 & 0.015 & 0.114 & 0.259 & 0.390 \\
\hline
\end{tabular}

